\title{
Plasma osteocalcin concentrations in cows around parturition. The influence of a regular versus a very short dry period
}

\author{
MJ Davicco 1, B Rémond 2, S Jabet 2, JP Barlet 1* \\ 1 UR Métabolisme Minéral; \\ 2 INRA Theix, UR Lactation, 63122 Saint-Genès-Champanelle, France
}

(Received 20 January 1992; accepted 9 June 1992)

\begin{abstract}
Summary - Plasma Ca, P, Mg and OC concentrations were compared between 2 groups of Holstein cows around 2 nd calving. Thirteen cows were milked until their daily milk production was lower than $2 \mathrm{~kg}$, which occurred $4 \mathrm{~d}$ before parturition. The control group ( 8 cows) was normally dried 8 weeks before the expected time of calving. Apart from the week following the initiation of the dry period where plasma OC concentrations were significantly lower in dried cows than in the control group (which would indicate lower bone remodeling in dried cows), no significant difference concerning $\mathrm{Ca}, \mathrm{P}, \mathrm{Mg}$ and $\mathrm{OC}$ concentrations were observed between the 2 groups of cows. This indicates that the only lack of 18 -week-long dry period probably has no major immediate effect upon $\mathrm{Ca}$ and bone metabolism in young dairy cows given a convenient $\mathrm{Ca}$ and $\mathrm{P}$ daily intake. Nevertheless, the lack of the dried period might protect the cow against parturient hypocalcemia: the decrease in plasma $\mathrm{Ca}$ and $\mathrm{P}$ concentrations observed $12 \mathrm{~h}$ after calving was less intense in non-dried cows than in controls.
\end{abstract}

cow / lactation / dry period / hypocalcemia / osteocalcin

Résumé - Influence du non-tarissement sur le métabolisme calcique de la vache laitière aux alentours de la parturition. Les concentrations plasmatiques en calcium (Ca), phosphore minéral $(P)$, magnésium $(\mathrm{Mg})$ et ostéocalcine (OC; un marqueur de l'activité ostéoblastique) ont été mesurées chez des vaches Holstein aux alentours du deuxième vêlage. Huit animaux ont été taris normalement 8 semaines avant la date prévue de vêlage. Les 13 autres ont continué à être traits jusqu'à ce que leur production devienne inférieure à $2 \mathrm{~kg}$ de lait par jour, c'est-à-dire jusqu'à 4 jours en moyenne avant vêlage. Chez les 21 vaches les concentrations plasmatiques en Ca et $P$ les plus faibles ont été observées $12 \mathrm{~h}$ après mise-bas. À l'exception de la semaine suivant le tarissement des 8 vaches chez lesquelles l'ostéocalcinémie était plus faible que chez les treize non taries (ce qui traduit vraisemblablement un brusque ralentissement du remodelage osseux chez les premières), nous n'avons observé aucune différence significative entre les paramètres plasmatiques mesurés dans les deux lots. Ainsi, la seule absence d'une période de tarissement de 8 semaines ne semble pas avoir d'effets immédiats très importants sur le métabolisme calcique et osseux de jeunes vaches laitières recevant une alimentation phosphocalcique équilibrée. Néanmoins, la baisse de la calcémie

\footnotetext{
* Correspondence and reprints
} 
et de la phosphatémie observée après vêlage étant moins intense chez les vaches non taries que chez les témoins, la suppression du tarissement pourrait avoir un effet prophylactique à l'encontre de l'hypocalcémie vitulaire.

vache / lactation / tarissement / hypocalcémie / ostéocalcine

\section{INTRODUCTION}

Bovine parturient paresis (milk fever) is a metabolic disorder occurring at the onset of lactation, when demands for calcium (Ca) and inorganic phosphorus $(P)$ are substantially increased (Braithwaite, 1976). These elements are secreted into milk at a faster rate than they are removed from bone (Yarrington et al, 1976) and absorbed from intestine (Hove and Hilde, 1984). Although a decrease in plasma $\mathrm{Ca}$ and $\mathrm{P}$ concentrations is a normal event in all parturient cows, the hypocalcemia and hypophosphatemia is far more important in paretic animals (Moodie et al, 1955; Larvor et al, 1961; Barlet, 1969). In pregnant dry cows, $\mathrm{Ca}$ metabolism is in balance: that is input from intestine and bone equals output into bone, feces, urine and fetus. At delivery, the exchange into the fetus stops, but the output to colostrum is greater than towards the fetus in the dry period and may induce hypocalcemia (Ramberg et al, 1970; Westerhuis, 1974). The parturient cow may, however, become resistant to hypocalcemia by enlarging the immediately available $\mathrm{Ca}$ pool, ie by decreasing Ca output from the blood, and/ or by increasing $\mathrm{Ca}$ input into the blood. Decreasing Ca output from the blood may be effected by incomplete milking for some days following calving. In fact the efficiency of milking during the days after parturition does not seem to have any significant influence on the incidence of milk fever in Ayrshire, Guernsey and Jersey cows (Owen, 1954). Decreasing
$\mathrm{Ca}$ input into the immediately available Ca pool just before calving would make Ca metabolism more adaptable. This can be done by removing $\mathrm{Ca}$ by milking pre-partum. In fact, results obtained by Smith and Blosser (1947) in a group of 46 cows and by Kendall et al (1968) using 22 animals do not support or reject this theory.

Working on the influence of the dry period length on subsequent milk production, Coppock et al (1974) also studied the incidence of parturient paresis in cows used in their experimental design. Sixty-five Holstein herds, with a minimum herd size of 50 cows, were assigned to dry periods of $20,30,40,50$ and $60 \mathrm{~d}$. These durations had no significant influence on parturient paresis which occurred in $13,12.5,11.8$, 12.4 and $13.3 \%$ of the animals of each group, respectively. Nobody has, however, observed the influence of the suppression of the dry period on plasma $\mathrm{Ca}, \mathrm{P}$ and osteocalcin (OC: a marker for bone remodeling (Delmas et al, 1986)) concentrations in dairy cows at parturition. This was the aim of the present study.

\section{MATERIALS AND METHODS}

\section{Animals}

Twenty-one Holstein cows were divided into 2 groups at the end of their first lactation. The predicted times for calving, milk production and milk composition during the first 4 months of the first lactation, the age of the animals at the first 
calving and their body weight were the criteria used for grouping of cows. Eight cows were normally dried 8 wk before the expected time of calving (in our herd the length of gestation is $281 \pm 9$ d (mean \pm SEM). The 13 other cows were milked until their daily milk production was lower than $2 \mathrm{~kg} / \mathrm{d}$. Thus the length of the dry period was $58 \pm 15$ days and $4 \pm 6 \mathrm{~d}$ for the dried (D) and non dried (ND) cows, respectively. During the experimental period each cow was fed grass silage, hay and grain concentrate. Fortyeight $h$ after calving, the body weight of the $D$ and ND cows was $662 \pm 56 \mathrm{~kg}$ and $661 \pm 57 \mathrm{~kg}$, respectively. During the first 2 wk after calving the daily dry matter (DM) intake increased in parallel in both groups and was not different in ND $(17.6 \mathrm{~kg})$ and $D(16.1 \mathrm{~kg})$ cows. Thus, the mean daily intake of each cow was $120 \mathrm{~g}, 80 \mathrm{~g}$ and $25 \mathrm{~g}$ for $\mathrm{Ca}, \mathrm{P}$ and $\mathrm{Mg}$, respectively. This corresponds to INRA dietary recommendations $(7 \mathrm{~g} \mathrm{Ca}$ and $4 \mathrm{~g} \mathrm{P}$ per $\mathrm{kg}$ dry matter intake for a daily milk production of $20 \mathrm{~kg}$ ) (Guéguen et al, 1988).

After calving each cow was milked twice daily, at 6 am and $5 \mathrm{pm}$. Daily milk production increased in parallel in both groups. It was lower in ND than in D cows and maximal $(27 \mathrm{~kg}$ and $33 \mathrm{~kg}$ for $\mathrm{D}$ and ND cows, respectively) during the 7 th week of lactation.

\section{Sampling and assays}

Heparinized blood samples were collected from each cow by puncture of the caudal vein before and during the dry period, $12 \mathrm{~h}$ after calving, and 10 and $70 \mathrm{~d}$ later. After centrifugation, plasma was frozen until analysis. Plasma $\mathrm{Ca}$ and $\mathrm{Mg}$ concentrations were measured by atomic absorption spectrophotometry. Plasma $\mathrm{P}$ was determined by colorimetry (Biotrol kit, Paris, France).

Plasma osteocalcin (OC) concentration was measured by homologous radioimmunoassay using the osteocalcin RIA kit from Incstar Corporation (Stillwater, MN, USA). In our experimental conditions, the sensitivity of the method was $0.15 \mathrm{ng} / \mathrm{ml}$. The intra- and interassay precision was 6 and $9 \%$ respectively.

Results are expressed as means \pm SEM. Student's $t$-test was used to compare values between the 2 groups of animals. One-way anal- ysis of variance was used for comparisons within 1 group of cows.

\section{RESULTS}

In both groups of cows parturition was associated with a significant decrease in plasma $\mathrm{Ca}$ and $\mathrm{P}$ concentrations (fig 1). In $D$ cows calcemia and phosphatemia decreased from $10.6 \pm 0.1 \mathrm{mg} / \mathrm{dl}$ and $8.3 \pm 0.4 \mathrm{mg} / \mathrm{dl}$ at first sampling to $10.1 \pm 0.1 \mathrm{mg} / \mathrm{dll}(P<0.05)$ and to $6.7 \pm$ $0.2 \mathrm{mg} / \mathrm{dl}(P<0.05)$ at parturition, respectively. At the same time, in ND cows, plasma $\mathrm{Ca}$ and $P$ concentrations decreased from $10.5 \pm 0.1 \mathrm{mg} / \mathrm{dl}$ and $6.7 \pm 0.3 \mathrm{mg} / \mathrm{dl}$ to $8.5 \pm 0.3 \mathrm{mg} / \mathrm{dl}(P<$ $0.01)$ and to $5.2 \pm 0.4 \mathrm{mg} / \mathrm{dl}(P<0.05)$, respectively. Twelve $h$ after calving, plasma $\mathrm{Ca}$ and $\mathrm{P}$ concentrations were lower in $D$ than in ND cows. On the other hand, plasma $\mathrm{Mg}$ concentrations (which were never significantly different in both groups) were then higher $(P<0.05)$ in $D(2.6 \pm 0.1 \mathrm{mg} / \mathrm{dl})$ than in ND cows (2.1 $\pm 0.1 \mathrm{mg} / \mathrm{dl})$.

in both groups of cows, plasma OC concentrations gradually decreased from the first sampling (ND: $28.8 \pm 3.2 \mathrm{ng} / \mathrm{ml}$; $\mathrm{D}: 26.3 \pm 3.1 \mathrm{ng} / \mathrm{ml}$ ) to calving (ND: $13.1 \pm$ $2.5 \mathrm{ng} / \mathrm{ml}(P<0.01) ; \mathrm{D}: 12.2 \pm 1.6 \mathrm{ng} / \mathrm{ml}$ $(P<0.01)$. A negative linear regression was observed between plasma OC concentrations $(y)$ and days before calving $(x)$ in both $\mathrm{D}(y=0.09 x+17.1 ; r=-0.402$; $P<0.05)$ and ND cows $(y=0.14 x+17.2$; $r=-0.506 ; P<0.01)$. Values measured $70 \mathrm{~d}$ after calving (ND: $25.5 \pm 2.6 \mathrm{ng} / \mathrm{ml}$; $\mathrm{D}: 30.1 \pm 3.5 \mathrm{ng} / \mathrm{ml}$ ) were not different from those measured in the first sampling. Plasma OC concentrations were never different in both groups of cows except those measured 50 days before calving, which were lower in $D(17.6 \pm 1.2 \mathrm{ng} / \mathrm{ml})$ than in ND cows $(24.7 \pm 1.8 \mathrm{ng} / \mathrm{ml} ; P<0.05)$. 

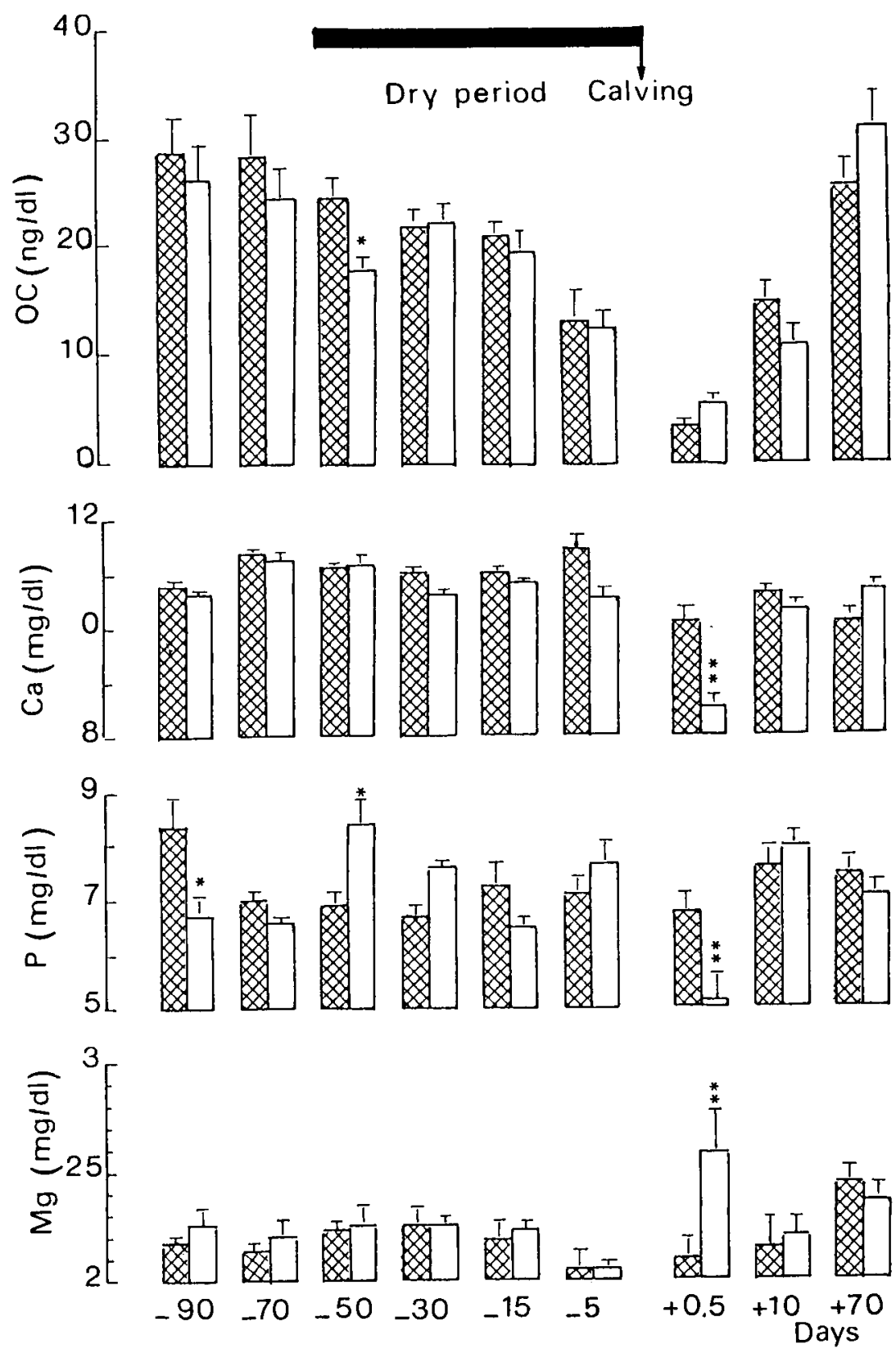

Fig 1. Plasma osteocalcin $(\mathrm{OC})$, calcium $(\mathrm{Ca})$, inorganic phosphorus $(\mathrm{P})$ and magnesium $(\mathrm{Mg})$ concentrations measured in 8 dried (white bars) and 13 continuously milked (hatched bars) Holstein cows at the second calving (means $\pm \mathrm{SEM} ;{ }^{*} P<0.05$, ${ }^{*} P<0.01$; comparison between the 2 groups of cows). 


\section{DISCUSSION}

In the bovine (Van Mosel and Corlett, 1990 ) as in the ovine (Farrugia et al, 1989; Pastoureau et al, 1991) and human species (Delmas et al, 1986) plasma OC concentrations are strongly correlated to osteoblastic activity and bone growth. Our results confirm previous studies demonstrating a decrease in plasma $O C$ concentration in cattle near parturition (Davicco et al, 1990; Naito et al, 1991) Thus, this would indicate a simultaneous reduction in osteoblastic activity (Van Mosel and Corlett, 1990). This might be due to a decrease in bone remodeling (and bone resorption) following the initiation of the dry period: plasma OC concentrations were lower in D than in ND cows immediately after milking stopped (fig 1). Such a difference was not observed between the 2 groups during the last $40 \mathrm{~d}$ of pregnancy. However, it must be borne in mind that during the last days of milking in ND cows, $\mathrm{Ca}$ intestinal absorption in these young (3yr-old) cows was probably high enough to supply $\mathrm{Ca}$ for a very low milk production (less than $5 \mathrm{~kg} / \mathrm{d}$ ) and thus to prevent active bone resorption.

No clinical symptom of parturient paresis was observed in these young animals (Braithwaite, 1976). The lowest values for plasma $\mathrm{Ca}$ and $\mathrm{P}$ concentrations were measured in both groups $12 \mathrm{~h}$ after calving, associated with the highest values for magnesemia (fig 1). A significant and still unexplained negative relationship has already been observed between plasma $\mathrm{Ca}$ and $\mathrm{Mg}$ concentrations in postparturient paretic (Marr et al, 1955; Blum et al, 1972) and healthy cows (Moodie et al, 1955).

Twelve $\mathrm{h}$ after calving plasma $\mathrm{Ca}$ and $\mathrm{P}$ concentrations were significantly higher in ND than in D cows (fig 1). This indicates that continuous milking might protect the cow against parturient hypocalcemia. How- ever, the way in which this protection might occur remains obscure. Parathyroid hormone-related peptide (PTHrP) is a newly characterized calciotropic factor which was originally isolated from tumors associated with the paraneoplastic syndrome of humoral hypercalcemia of malignancy (Broadus et al, 1988; Martin and Suva, 1989). PTHrP might be the putative calciotropic factor functioning during lactation: it has biological effects very similar to PTH (Horiuchi et al, 1987; Orloff et al, 1989); it is synthetized in lactating mammary tissue (Thiede and Rodan, 1988; Ratcliffe et al, 1992) and increases calcium and phosphorus secretion into milk (Barlet et al, 1992); in rats, serum levels of PTHrP are increased during lactation and this coincides with stimulation of bone resorption (Miller et al, 1991).

Thus, higher plasma PTHrP levels in ND than in $D$ cows might be responsible for higher plasma $\mathrm{Ca}$ concentrations measured in these animals after calving (fig 1). This would not explain higher plasma $P$ concentrations (fig 1) since PTHrP is a hyperphosphaturic and hypophosphatemic hormone (Horiuchi et al, 1987). However, PTHrP can increase plasma 1,25-dihydroxyvitamin $D_{3}$ concentrations (Horiuchi et al, 1987; Barlet et al, 1990). These would stimulate $\mathrm{Ca}$ and $P$ intestinal absorption, and thus prevent hypocalcemia and hypophosphatemia (fig 1). It has recently been demonstrated that suckling or milking increases plasma PTHrP concentrations in lactating rats (Yamamoto et al, 1991) and goats (Ratcliffe et al, 1992), respectively. However, the effect of milking on plasma PTHrP concentrations in dairy cows remains unknown.

In conclusion, our results indicate that the only suppression of a 60-d dry period does not seem to have a long-lasting effect on bone and $\mathrm{Ca}$ metabolism (as evaluated by plasma $\mathrm{Ca}, \mathrm{P}$ and $\mathrm{OC}$ concentrations) in young, adequately fed dairy cows. Nev- 
ertheless, higher plasma $\mathrm{Ca}$ and $\mathrm{P}$ concentrations measured in non-dried cows just after calving indicate that continuous milking might have a protective effect against parturient hypocalcemia.

\section{ACKNOWLEDGMENTS}

We thank $J$ Rouel and his team at Orcival INRA Experimental Station for the technical management of the trial and the sampling.

\section{REFERENCES}

Barlet JP (1969) Variations de la calcémie et de la phosphatémie chez la vache laitière au moment du vêlage: rôle probable de la calcitonine dans l'étiologie du syndrome vitulaire. Rech Vét 2, 93-100

Barlet JP, Davicco MJ, Coxam V (1990) Synthetic parathyroid hormone-related peptide (1-34) fragment stimulates placental calcium transfer in ewes. $J$ Endocrinol 127, 33-37

Barlet JP, Champredon C, Coxam V, Davicco MJ, Tressol JC (1992) Parathyroid hormonerelated peptide might stimulate calcium secretion into milk of goats. $J$ Endocrinol 132 , 353-359

Blum JW, Ramberg CF, Johnson KG, Kronfeld DS (1972) Calcium (ionized and total), magnesium, phosphorus and glucose in plasma from parturient cows. Am J Vet Res 33, 5156

Braithwaite GD (1976) Calcium and phosphorus metabolism in ruminants with special reference to parturient paresis. J Dairy Res 43 , 501-520

Broadus $A E$, Mangin $M$, Ikeda $K$, Insogna $K L$, Weir EC, Burtis WJ, Stewart AF (1988) Humoral hypercalcemia of cancer: indentification of a novel parathyroid hormone-like peptide. N Engl J Med 319, 556-563

Coppock CE, Everett RW, Natzke RP, Ainslie HR (1974) Effect of dry period length on Holstein milk production and selected disorders at parturition. J Dairy Sci 57, 712-718

Davicco MJ, Coxam V, Roux R, Barlet JP (1990) Plasma osteocalcin concentrations in cattle under various pathophysiological conditions. Bone Min 10, 131-137

Delmas PD, Derniaux B, Malaval L, Chapuy MC, Edouard C, Meunier PJ (1986) Serum bone gla-protein (osteocalcin) in primary hyperparathyroidism and in malignant hypercalcemia. Comparison with bone histomorphometry. J Clin Invest 77, 985-991

Farrugia W, Fortune CL, Heath J, Caple IW, Wark JD (1989) Osteocalcin as an index of osteoblast during and after ovine pregnancy. Endocrinology 125, 1705-1710

Guéguen L, Lamand $M$, Meschy $F$ (1988) Nutrition minérale. In: Alimentation des Bovins, Ovins, Caprins (Jarrige R, ed) INRA Publications, Paris, 95-111

Horiuchi N, Carslfield MP, Fisher JE, Goldman ME, Mc Kee RL, Reagan JE, Levy JJ, Nutt RF, Rodan SB, Schofield TL, Clemens TL, Rosenblatt M (1987) Similarity of synthetic peptide from human tumor to PTH in vivo and in vitro. Science 238, 1566-1568

Hove K, Hilde BL (1984) Plasma calcium in the lactating cow: dependence on continuous intestinal aborption. Can J Anim Sci 64 (suppl), 227-228

Kendall KA, Harshbarger KH, Hays RL, Ormiston EE (1968) Blood mineral levels associated with prepartum milking. J Anim Sci 237, 1769 (Abstr)

Larvor $P$, Brochart $M$, Théret $M$ (1961) Enquête sur la fièvre vitulaire et la tétanie d'herbage des bovins en France. Econ Med Anim 2, 5-38

Marr A, Moodie EW, Robertson A (1955) Some biochemical and clinical aspects of milk fever. J Comp Pathol 65, 347-365

Martin TJ, Suva LJ (1989) Parathyroid hormonerelated peptide in hypercalcemia of malignancy. Clin Endocrino/ 31, 631-647

Miller SC, Bagi CM, Bowman BM (1991) Increased serum levels of parathyroid hormone-related peptide correlate the activation of bone resorption and remodeling during early lactation in rats. Calcif Tissue Int 48 (suppl), A 13 (abstr)

Moodie EW, Marr A, Robertson A (1955) Serum calcium and magnesium and plasma phosphate levels in normal parturient cows. $J$ Comp Pathol 65, 20-36

Naito Y, Shindo N, Sato R, Murakami D (1991) Plasma osteocalcin in preparturient and 
postpaturient cows: correlations with plasma 1,25-dihydroxyvitamin D, calcium and inorganic phosphorus. J Dairy Sci 73, 3481-3484

Orloff JJ, Wu TL, Stewart AF (1989) Parathyroid hormone-like protein: biochemical responses and receptor interactions. Endocr Rev 10, 476-495

Owen JR (1954) The effect of complete milking at calving time on the incidence of milk fever and the subsequent effect on the cow and calf. State College Inf Sheet 497. Missouri Agr Expt Statrio

Pastoureau P, Meunier PJ, Delmas P (1991) Serum osteocalcin (bone gla - protein), an index of bone growth in lambs. Comparison with age-related histomorphometric changes. Bone 12, 143-149

Ramberg CF, Mayer GP, Kronfeld DS, Phang JM, Berman M (1970) Calcium kinetics in cows during late pregnancy, parturition and early lactation. Am J Physiol 219, 1166-1177

Ratcliffe WA, Thompson GE, Care AD, Peaker $M$ (1992) Production of PTH-related protein (PTHrP) by te mammary gland of the goat. $J$ Endocrinol 133, 87-93

Smith VR, Blosser TH (1947) Parturient paresis. I. The incidence of parturient paresis and changes in the total blood serum calcium at parturition in prepartum milked cows. $J$ Dairy Sci 30, 861-866

Thiede MA, Rodan GA (1988) Expression of calcium-mobilizing parathyroid hormone-like peptide in lactating mammary tissue. Science $242,278-280$

Van Mosel M, Corlett SC (1990) Assessment of bone turnover in the dry period of dairy cows by measurement of plasma bone gla-protein, total plasma alkaline phosphatase activity and urinary hydroxyproline. Exp Physiol 75, 827-837

Westerhuis JH (1974) Parturient hypocalcemia prevention in parturient cows prone to milk fever by dietary measures. Agric Res Rep 814. Agric Publ Doc, Wageningen, 1-78

Yamamoto M, Duong LT, Fisher JE, Thiede MA, Caulfield MP, Rosenblatt M (1991) Sucklingmediated increases in urinary phosphate and $3^{\prime}, 5^{\prime}$-cyclic adenosine monophosphate excretion in lactating rats: possible systemic effects of parathyroid hormone-related protein. Endocrinology 129, 2614-2622

Yarrington JT, Capen CC, Black $H E$, Re R, Potts JT, Geho WB (1976) Experimental parturient hypocalcemia in cows following prepartal chemical inhibition of bone resorption. Am J Pathol 83, 569-588 